\title{
The Effect of IFRS Adoption on the Readability of Annual Reports: An Empirical Study of Indonesian Public Companies
}

\author{
Irfan Hidayatullah ${ }^{1}$, Dyah Setyaningrum ${ }^{2 *}$ \\ 1,2 Faculty of Economy and Business, University of Indonesia, \\ Jl. Salemba Raya, Depok 16424, Jakarta, Indonesia \\ Corresponding author; Email: Irfanhidayat1@yahoo.co.id; $2^{\star}$ dyah.setyaningrum1978@gmail.com
}

\begin{abstract}
This study aims to determine the effect of IFRS adoption on the readability of annual reports readability in Indonesia. The sample of this study includes 52 non-financial firms within a four-year period, from 2010-2011 and 2013-2014, with 208-year observations. Hypothesis testing is conducted by multiple linear regression analysis. This study provides evidence that IFRS adoption has significant and negative relationship with disclosure readability in Indonesian public companies. Implication of this study is IFRS adoption requires more sophisticated and/or more competent users of financial statements, measured by higher requirements of years of education needed to comprehend the disclosures.
\end{abstract}

Keywords: Annual reports; disclosure; IFRS adoption; readability.

\section{INTRODUCTION}

As one of the sources of information on decision making, financial statements are prepared based on applicable accounting standards to produce relevant and reliable information. The existence of accounting standards that are used globally will certainly improve comparability and make it easier for users of financial statements to make decisions. International Accounting Standard Boards (IASB) mentioned that accounting standards is a principle that has to be followed by companies in preparing and publishing financial statements. The need for international standards is increasing because of the evolution of the global economy, cross country loans/investments and increasing emphasis on international harmonization [23]. The adoption of international accounting standards into local accounting standards has the purpose of producing financial reports that have high credibility [29].

Nowadays, many countries have adopted International Financial Reporting Standards (IFRS) into local accounting standards. The strategy of IFRS adoption consists of the big bang strategy and gradual strategy. In the big bang strategy, IFRS was fully adopted without certain stages, while in gradual strategy, IFRS was adopted gradually. Big bang strategy has been used by developed countries, such as European Union countries, Australia, Hong Kong, and New Zealand; while other countries such as Indonesia, Malaysia and the Philippines chose to carry out IFRS convergence gradually [30]. Indonesia uses gradual strategy due to limited resources [39]. The development of financial accounting standards in Indonesia initially referred to the US Generally Accepted Accounting Principles (US GAAP), however, since 2008 Indonesia has begun to gradually adopt International Financial Reporting Standards (IFRS).

The IFRS application does not mean without constraints. One of the problems with IFRS is the large volume of disclosures needed [13]. Previous research has shown information overload in financial reports after IFRS implementation [24], [28]. The impact of excess load content is low readability [22]. Preparation of financial statements must meet several qualitative characteristics, one of which is understandability (Conceptual Framework for Preparation and Presentation of Financial Statements). Understandability is a concept related to readability. Readability, in conjunction with accounting narrative statements, is defined as "the difficulty of the text and success in accounting message communication" [32]. Readability is a factor considered in analyzing the ease of understanding the material [31]. Research on readability has been carried out in accounting texts, and usually focuses on elements of annual reports, specifically the management discussion section and financial statements [7], [17], [27], [33]. The annual report is the main source of investors in making decisions; therefore, it is important for users to understand and understand the information contained in annual reports [17].

Current research discusses several determinants to the readability of disclosure in annual report. There is a positive association between corporate social performance and Management's 
Discussion and Analysis (MDA) textual complexity [3]. Business strategy does impact annual report readability [19]. The firms pursuing an innovationoriented prospector strategy have less readable 10$\mathrm{Ks}^{1}$ relative to firms pursuing an efficiencyoriented defender strategy. There is also a positive association between managerial ability with the readability of narrative disclosure in $10-\mathrm{K}$ reports; and this association is more pronounced for firms with high levels of profitability [14].

The economic impact of financial disclosure readability is investigated by [4]. They found that less readable financial disclosures are associated with less favorable ratings, greater bond rating agency disagreement and a higher cost of debt. It is found that firms most likely to manage earnings to beat the prior year's earning have MDA that are more complex. Previous research also discussed the impact of IFRS adoption to annual report readability [20]. The impact of IFRS adoption on the readability of annual report disclosures are examined at NZX50 companies [31]. The result shows that there is a relationship between IFRS adoption and a decrease in the readability, which is measured by the Flesch, Smog and Fog readability formula. The impact of IFRS adoption on the readability of annual report disclosures are also examined at companies listed on the Australian Stock Exchange between 2001 and 2009. IFRS adoption in Australia had a positive impact on the readability of financial statements, and there was no change in relations between readability and company performance. There is also research that compare the readability of the annual report of companies adopting IFRS with companies that do not adopt IFRS in Korea [15]. The results show that IFRS adopting companies have annual reports that are significantly more complicated than the annual reports of companies not adopting IFRS. Therefore, it can be concluded that previous research gave mixed results regarding the effect of IFRS adoption on the readability of annual reports.

In Indonesia, there are no studies that examine the impact of IFRS adoption on readability. Many studies on the impact of IFRS adoption in Indonesia are still limited to the value relevance [6], [36]. The effect of IFRS adoption on the length of financial statements are examined in the companies listed on the Indonesia Stock Exchange [28]. The results study show that there are differences between the notes to financial statements during the period of IFRS adoption when compared to the

\footnotetext{
${ }^{1}$ Form $10-K s$ report accounting numbers prepared in accordance with US accounting standards, as well as unstructured textual narratives disclosing accounting policies and describing business operations and financial performance.
}

period before IFRS adoption. However, this research focuses on the content of information contained in financial statements and not on their relation to readability. Therefore, this study will revisit [31] using Indonesian context.

Based on the description above, this study aims to provide empirical evidence regarding the effect of IFRS adoption on the readability of financial statement disclosures in Indonesia. This study compares the level of readability of financial statement disclosures in Indonesia before and after the period of IFRS adoption. Therefore, the period of this study covered the years before and after IFRS was fully adopted in Indonesia, years 2010-2011 is chosen to represent the period before IFRS adoption and 2013-2014 as the period after IFRS adoption.

This paper contributes to the literature in several ways. First, the IFRS adoption in Indonesia is interesting because Indonesia adopted IFRS gradually. This is different from previous studies which observed in countries that fully adopted IFRS, therefore, the results might be different from previous studies. Indonesia gradually adopted IFRS since 2012 by using convergence towards IFRS. The convergence creates several differences between IFRS and Indonesian Accounting Standard (PSAK), including conceptual, editorial, and effective date differences [21]. Second, this study is expected to be a consideration for regulators to overcome problems that might arise in the implementation of IFRS. The complexity of disclosure after IFRS implementation make financial statements disclosure is difficult to read and less readability has negative impact to the companies such as higher cost of debt [4] and ways hide earnings management [20].

\section{Theoretical Review and Hypothesis Develop- ment}

According to the Conceptual Framework for Preparation and Presentation of Financial Statements (IAI, 2016), so that financial information becomes useful, the information must be relevant and accurately represent what will be represented. In addition, the value of the information usefulness can be increased by the following qualitative characteristics:

1. Understandability: information in financial statements should make it easier for users to understand it. The user is assumed to have adequate knowledge of the economic and business activities of the company, accounting, and the ability to learn information to be able to understand financial statements. 
2. Timely: information is available to decision makers at the right time so that it can influence the decisions of users of financial statements.

3. Verifiability: convince users of financial statements that information represents the economic phenomenon appropriately as it should.

4. Comparability: users can identify and understand similarities, and differences between periods.

Because the importance of qualitative characteristics is not easy to understand, some regulators such as the Securities and Exchange Commission (SEC) are continually trying to make public company prospectuses more readable and understandable. Problems will arise if financial statements do not meet understandable criteria. If financial statements are not easily understood, this will reduce the quality of financial reporting itself, because investors and users of financial statements are faced with an excessive burden in taking information in financial statements [18].

IFRS is developed by the International Standard Boards (IASB) with the aim of developing a set of high-quality, understandable, enforceable and globally accepted financial reporting standards, based on clearly stated accounting principles. (IASB, 2010). The existence of globalization which is characterized by the loss of boundaries between countries makes the need for the use of accounting standards that apply internationally and the harmonization of accounting standards is much more important than before. In Indonesia, the harmonization of the Statement of Financial Accounting Standards (PSAK) has been decided since 1994 by the Financial Accounting Standards Board. The harmonization has changed to the adoption carried out in the form of convergence towards IFRS. According to the Indonesian Accounting Association (IAI), IFRS convergence in Indonesia is carried out in three stages, namely (1) adoption stage (2008 - 2011), where all IFRS is adopted into PSAK, the required infrastructure is prepared, and the applicable PSAK is evaluated ; (2) the final preparation stage (2011), in which phased implementation of several IFRS-based PSAKs, and the completion of infrastructure preparation is carried out; and (3) the implementation phase (2012), where almost all PSAKs applied refer to IFRS. Evaluations were also carried out on the impact of implementing the SFAS comprehensively. As of January 1, 2012, all IFRS has been converge into local PSAK, with the exception of IFRS 1 First-time Adoption of International Financial Reporting Standards, IAS 1 Agriculture, and IFRIC 15, Agreements for the Construction of Real Estate.
Readability formula is a mathematical equation derived from regression analysis, where the model or equation that is built predicts the education level of the reader needed to be able to understand the text given [31]. Readability formula is an objective method in predicting whether a narrative text can be read by the target reader. The readability formula produces an easy reading score from the measured reading and indicates whether the reading can be read and understood from the intended reader [7]. The result of the readability index is the prediction of the reader's education level needed to understand the text measured from the year of education, with the level of education in the United States. The higher the level of education needed, the more difficult the text to read.

The readability formula has limitations. The readability formula only focuses on analyzing syntactic difficulties. Furthermore, the readability formula also cannot determine the level of interest, knowledge, education and experience that affect understanding [2]. Technical documents may be easier to read by someone with an understanding of specialized vocabulary, and a knowledge base that is not shared by general readers [37]. Readability formula uses "average" readers to calculate the level of difficulty in reading the writing. There is also show problems if the readability formula is used with technical material, because this can result in a level of difficulty that is too high [10]. Although not without its own limitations, the readability formula is popularly used in accounting for reasons of convenience and can be verified [35]. Readability formula is an objective method in predicting the possibility of a narrative can be understood by the reader [7]. If the readability formula is used correctly, the readability formula can be a reliable tool in determining the difficulty level of the narrative [31]. Until now, research on the complexity of annual reports still uses the readability formula approach, while acknowledging the limitations of the approach. The study of readability generally focuses on elements of the company's annual report, specifically, the management discussion section and notes to financial statements [7], [10], [17], [27].

\section{Hypothesis Development}

The results of previous studies indicate mixed evidence of the relationship between IFRS adoption and the readability of annual reports [15], [31]. It is found that IFRS adoption affected the readability of NZX50 company annual disclosures [31]. Disclosure of annual reports in the period after IFRS adoption becomes more difficult to read. The readability of annual reports also compared bet- 
ween 57 companies adopting IFRS and 943 companies that did not adopt [15]. The results show that the readability of annual reports based on IFRS is significantly lower compared to financial statements prepared based on local accounting standards. However, the results of the study show that notes on Australian companies' financial statements are easier to read after the period of IFRS adoption, although the reports have increased in length. From previous research, it can be concluded that the results regarding the relationship between IFRS adoption indicate mixed evidence.

Research on the readability of financial statement disclosures uses the readability formula to predict the difficulty level of the text. Frequently used formulas, such as the Flesch-Kincaid index and the Fog index, predict the level of education needed to understand a text. The readability formula is a function of the length of the word (calculated from the number of syllables in one word) and the length of the sentence (calculated from the number of words in a sentence), so that longer text does not always result in worse readability. Longer text can be easier to read if the text is arranged in short sentences. Flesch (n.d.) argues that sentence lengths and word lengths are related to readers' short-term memory. The longer the sentence, the harder it is to process a sentence, so that the burden of the reader increases, and the readability of a text decreases. Therefore, a longer text can be easier to read if the text is composed of short sentences and words. This explains why previous research shows a mixed result between the effect of IFRS adoption and the readability of annual report disclosures. In addition, the disclosures required in IFRS are quantitative and qualitative. Quantitative disclosures can be presented in the form of tables or explanations in the form of paragraphs in the notes to financial statements. Disclosures under IFRS only require the type and nature of information to be disclosed, without regulating how the information must be disclosed. In other words, companies can make more disclosures but are easier to read, if the disclosures are arranged in such a way using shorter sentence. Therefore, expectations regarding the level of readability after the period of IFRS adoption cannot be determined.

Because the results of different previous studies and expectations cannot be determined, it is difficult to form the direction of the hypothesis. Therefore, this study predicts the hypothesis as follows:

H1: Adoption of IFRS has an effect on the level of readability of disclosures in the annual report.

\section{RESEARCH METHOD}

The data used in this study are secondary data in the form of annual reports of companies listed on the Stock Exchange in 2010-2014, with the exception of 2012. Financial data is taken from Thomson Reuters Eikon and annual reports for each company. This study has a population in the form of financial statements of public companies listed on the Indonesia Stock Exchange (IDX) from 2010-2014. This research period covers the year before and after IFRS was fully adopted in Indonesia. Indonesia began to fully adopt IFRS into the PSAK starting in 2012. Therefore, 2012 was excluded because it was the first year IFRS was fully adopted in Indonesia. Years 2010-2011 represent the period before IFRS adoption and 20132014 as the year after IFRS adoption. The criteria used in the selection of samples are as follows: (1) companies listed on the IDX in 2010-2014; (2) issuing complete financial statements in a row in 2010-2011 and 2013-2014; (3) publish financial statements in English; (4) not including companies engaged in the banking or financial services industry; (5) does not have a negative equity balance.

The research model used is the linear regression model as follows:

$$
\begin{gathered}
\text { Readability } i, t=\propto+\beta_{1}(\text { IFRS })_{i, t}+\beta_{2}(\text { Leverage })_{i, t} \\
+\beta_{3}(\text { Volatility })_{i, t}+\beta_{4}(\text { Size })_{i, t} \\
+\beta_{5}(\text { Industry })_{i}+\varepsilon_{i, t}
\end{gathered}
$$

The dependent variable is readability of disclosure of annual reports. In line with [18], the readability of annual reports is measured by proxy Fog index readability and annual report length. Readability index gives a score in the form of education years that the reader must take to understand the text. The level of education used is the level of school education in the United States, where school is taken for 12 years and undergraduate courses are taken for 4 years. The readability index measurement only applies to text in English; therefore, this study uses English-language financial report in the disclosure section of financial statements. The result of the readability index calculation is the estimation of the education year that the reader needs to take to understand the text, so that the higher the readability index value, the more difficult it is for a text to be read. Reading experts determine that technical material should not produce a score higher than 14, and business material is not higher than level 12 . The way to calculate the Fog readability index is as follows:

Fog $=0.4 \times($ Number of words per sentence + percentage of complicated words) 
where the number of words per sentence is calculated by dividing the total number of words in a text divided by the number of sentences in the text. Complex words are defined as words with more than three syllables. The percentage of complicated words is calculated by dividing the number of words that have three syllables or more with the number of words contained in the text to be measured. For example, the sentence "Cost is determined by the weighted average method" has 8 words, 1 sentence and 2 complicated words. Measurements with the Fog index produce a score of 13.2, which means 13 years of education are needed to understand the sentence. In addition to the Fog readability index, this study also uses disclosure length as a readability proxy variable.

To get the readability value from the disclosure of financial statements, financial report files are downloaded first in PDF format. After the financial statements have been downloaded, the disclosure section is converted in text format (plain text format) with Adobe Reader Pro software. In the conversion process, the text file is cleaned so that it can be read by the readability index counting software, and the text in non-paragraph forms (such as tables) is omitted. The process of calculating readability index is done with the Lingua :: EN :: Fathom package in the Perl programming language.

This study uses the independent variable of IFRS adoption. This independent variable is dummy variable that scores 1 for the years 20132014 and 0 for the years 2010-2011. In addition, this study uses control variables: Company size (Size), leverage, business instability (Volatility), and industry classification (Industry). Company size is defined as the natural logarithm of market value (in thousands) in the fiscal year. Company size can capture many aspects of the company's operational and business environment [18]. Larger companies have longer and more complicated disclosures [5]. The measurement of company size in this study refer to [1].

Leverage shows the proportion of the company's debt to equity. Leverage has positive relationship with the level of disclosure, because after IFRS implementation additional disclosures are needed related to financial instruments, agreements loans and risks. It is found that there was a significant positive relationship between company leverage and disclosure [5].

The third control variable is volatility. Stock price volatility is an indicator of business instability, and measured by a standard deviation from closing stock prices adjusted weekly for each relevant year. The closing stock price is taken from Yahoo Finance for each company observed and imported into Microsoft Excel to calculate standard deviation for each year. There is a positive relationship between stock price volatility and Fog values from company disclosures [18].

Companies in certain industries may have reports more complex disclosures. In this study, indicator variables are made for each company industry classification, with value (1) for companies operating in particular industry and (0) for companies that do not operate in the particular industry [18]. Industrial classification referring to [31], with the industrial sector energy, goods, industrial, primary, and services.

Data analysis conducted in this study is descriptive statistics and inferential statistics Descriptive statistics are used to describe and describe the variables in this study. The analytical tool used is the average value (mean), maximum and minimum values and standard deviation (standard deviation). Inferential statistics are used to draw conclusions from the results of research. Inferential statistics are carried out by testing research models and statistical testing [25].

\section{RESULTS AND DISCUSSION}

The results of descriptive statistics can be seen in table 1. The Fog index produces estimates of the level of education needed to understand the text, measured in years of education. This means that the higher the Fog value, the harder the text to read.

Table 1. Descriptive Statistics

\begin{tabular}{lccccc}
\hline \multicolumn{1}{c}{ Variable } & $\begin{array}{c}\text { Obser- } \\
\text { vation }\end{array}$ & Mean & $\begin{array}{c}\text { Std. } \\
\text { Deviation }\end{array}$ & Min & Max \\
\hline Pre-IFRS & & & & & \\
Fog Index & 104 & 15,148 & 1,546 & 12,83 & 20,18 \\
Disclosure Length & 104 & 20.250 & 8.252 & 8.411 & 51.732 \\
\hline Post-IFRS & & & & & \\
Fog Index & 104 & 15,588 & 1,992 & 13,26 & 20,4 \\
Disclosure Length & 104 & 24.189 & 8.699 & 10.990 & 49.377 \\
\hline Control Variable & & & & & \\
Size & 208 & 15,330 & 1,906 & 10,597 & 19,487 \\
Leverage & 208 & 1,166 & 3,725 & 0 & 47,751 \\
Volatility & 208 & 308,194 & 472,415 & 0,138 & $3.681,561$ \\
\hline
\end{tabular}

The Fog index show a mean score of 15.148 before the period of IFRS adoption, and 15.588 after the period of IFRS adoption. This means the reader with two years college education is needed to understand financial statement disclosures, or in other words, financial statement disclosures in Indonesia are difficult to read. When viewed from the minimum and maximum values, it can be seen that the readability index value has a high diversity, ranging from 12.83 or the equivalent to last year high school, up to 20.4 or equivalent to postgraduate students. These results are consistent 
with the findings of previous studies which found that disclosure of annual reports after IFRS adoption is difficult to read, with readability indices ranging from bad to very bad [7], [18], [33]. This study also measures readability based on length of disclosure. The average length of disclosure in the period before adoption was 20,250 words, and 24,189 words in the period after IFRS adoption. Data distribution also increases after the adoption period, indicated by standard deviation which increases in the period after adoption.

Table 1 above also shows descriptive statistics for control variables. Each variable has a large range of values, which indicates the diversity of companies included in this observation. The sample size of the company in this study has a large distribution, with a standard deviation of $\mathrm{Rp} 46$ trillion. Another control variable used in this study is stock volatility, which is an indicator of changes in stock prices. The higher the volatility of the stock, the higher the stock price fluctuates. The leverage variable describes the proportion of corporate debt to shareholders' capital, with the average sample company having a debt of 1.16 times the value of its capital, meaning that the average company in this sample has a debt of 1.16 times the total capital. When viewed by industry classification, companies with the services sector are the most companies in the sample of this study (amounting to 32.7\%), followed by companies in the industrial sector at $25 \%$. Consumer goods sector companies, primary sectors and the energy sector have a proportion of $23.1 \%, 11.5 \%$ and $7.7 \%$ of the total sample companies.

Before test the hypothesis, we conducted a mean different test to see the direction and significance of each dependent variable measurement. We compare readability index before and after IFRS adoption using Wilcoxon Signed Ranks, and t-test with paired samples.

Table 2. Mean Difference Test

\begin{tabular}{|c|c|c|c|c|}
\hline \multirow{2}{*}{$\begin{array}{l}\text { Measure- } \\
\text { ment }\end{array}$} & \multicolumn{2}{|c|}{ Wilcoxon Test } & \multicolumn{2}{|c|}{ T-test } \\
\hline & Significance & Directio & Significance & Direction \\
\hline Fog Index & $\begin{array}{c}\text { Significance } \\
\text { at } \alpha=0,05\end{array}$ & Increase & $\begin{array}{c}\text { Significance } \\
\text { at } \alpha=0,01\end{array}$ & Increase \\
\hline $\begin{array}{l}\text { Disclosure } \\
\text { Length }\end{array}$ & $\begin{array}{c}\text { Significance } \\
\text { at } \alpha=0,01\end{array}$ & Increase & $\begin{array}{c}\text { Significance } \\
\text { at } \alpha=0,01\end{array}$ & Increase \\
\hline
\end{tabular}

From the results of the mean difference tests above, it can be seen that each readability measurement, both with the Fog Index and the length of disclosure, experienced significant and unidirectional changes. This shows that there has been a decrease in the level of readability after the period of IFRS adoption. The hypothesis testing shown in table 3.
Table 3. Hypothesis Testing

\begin{tabular}{lccc}
\hline \multicolumn{1}{c}{ Fog } & $\begin{array}{c}\text { Expected } \\
\text { Sign }\end{array}$ & Coefficient & P-value \\
\hline IFRS & + & 0,456 & $0,003^{* * * *}$ \\
Size & + & 0,101 & 0,224 \\
Leverage & + & $-0,036$ & 0,207 \\
Volatility & + & 0,001 & $0,000^{* * *}$ \\
Energy & & 1,255 & $0,091^{*}$ \\
Industrial & & $-0,388$ & 0,420 \\
Primary & & 0,416 & 0,516 \\
Services & & $-0,112$ & 0,809 \\
Constant & & 13,783 & 0,000 \\
Observation & 208 & $*$ Significance at $\alpha=10 \%$ \\
Prob $>$ Chi2 & 0,0096 & $* *$ Significance at $\alpha=5 \%$ \\
R-squared within & 0,0596 & $* * *$ Significance at $\alpha=1 \%$
\end{tabular}

Description: Fog: readability index which is a Fog index, IFRS: dummy variable that describes IFRS adoption period, value 1 for the period after adoption and previous 0, Size: company size calculated from the company's natural equity market logarithm, Leverage: composition of interest bearing loans from the company, Volatility: the instability of the company's stock price which is calculated by the standard deviation of the weekly closing price of company shares, Energy, Industrial, Primary and Services: a dummy variable to describe each industry in which the company operates.

Table 3 shows the results of regression testing with a random effect model. Readability index measures the level of education needed to understand the text, so the higher the readability index, the more difficult the text to read. Therefore, the positive coefficient indicates the existence of a negative relationship between the IFRS adoption with the readability of the disclosure of the annual report. Based on the regression results above, it can be seen that there is a relationship between IFRS adoption and the difficulty level of the text which is significant at the level of $1 \%$. In other words, IFRS adoption has an impact on the disclosure of financial statements that are increasingly difficult to read. The results of hypothesis testing indicate a positive relationship with the level of education needed to understand the text. Because the higher the level of education needed, the more difficult the text to read, the positive relationship above shows a negative (inverse) relationship with readability. The results that show a negative relationship between the readability of financial statement disclosures and IFRS adoption are in line with the research of [15] and [31].

One characteristic of IFRS is that it requires more disclosure both quantitatively and qualitatively [21]. Qualitative disclosures are carried out with explanations in the form of narratives. Disclosures required by the IFRS regulate the type of information disclosed, and not from the selection of sentences. Therefore, financial report preparers 
still have the freedom to choose sentences. Because the readability formula is a function of sentence length and word length, this can occur if the preparers of financial statements uses longer sentences in disclosure after the period of IFRS adoption. It can also be concluded that there is a trade-off between the representational faithfulness with understandability. This can be seen from the negative relationship between IFRS adoption and the readability of disclosures. Financial statements after the period of IFRS adoption require not only more disclosure, but are more complicated and require more competent users who are higher in understanding financial statements.

This test also uses control variables that can affect the readability of financial statement disclosures. The test results in table 3 show that there are insignificant between the size and leverage with the readability of annual report disclosures, with the exception of volatility variables and the classification of the energy sector industry. This shows that companies with more volatile stock prices and companies in the energy industry have more complicated financial reports.

In addition to using the readability index variable, we also conducted a robustness test using the disclosure length as a proxy for readability. Following [18], researchers used the number of words as a measure of the length of financial statement disclosures. Table 4 below shows the results of linear regression analysis using length of disclosure.

Table 4. Robustness Test

\begin{tabular}{lccl}
\hline \multicolumn{1}{c}{ Variable } & $\begin{array}{c}\text { Expected } \\
\text { Sign }\end{array}$ & Coefficient & P-value \\
\hline IFRS & + & 0,173 & $0,000^{* * *}$ \\
Size & + & 0,062 & $0,000^{* * * *}$ \\
Leverage & - & $-0,007$ & $0,061^{*}$ \\
Volatility & - & $-0,000$ & 0,410 \\
Energy & + & 0,502 & $0,002^{* *}$ \\
Industrial & + & 0,164 & 0,143 \\
Primary & + & 0,345 & $0,015^{* *}$ \\
Services & + & 0,259 & $0,015^{* *}$ \\
Constant & & 0,173 & $0,000^{* * *}$ \\
\hline Observation & 208 & $*$ Significance at $\alpha=10 \%$ \\
Prob $>$ Chi2 & 0.000 & $* *$ Significance at $\alpha=5 \%$ \\
R-squared within & 0.327 & $* * *$ Significance at $\alpha=1 \%$
\end{tabular}

Description: Length: proxy readability measured by length of disclosure, IFRS: dummy variable that describes the period of IFRS adoption, value 1 for the period after adoption and previous 0, Size: company size calculated from the company's natural equity market logarithm, Leverage: loan composition interest from the company, Volatility: instability in the company's stock price calculated by the standard deviation of the weekly closing price of the company's shares, Energy, Industrial and Services: a dummy variable to describe each industry in which the company operates
Based on the regression results above, it can be seen that the IFRS adoption variable has a significant relationship to the length of financial statement disclosures. This is in line with [31]. Each control variable, both the size of the company variable (size), leverage and the classification of the energy sector industry (energy), industrial sector (industrial) and services (services) have a significant relationship to the length of disclosure. When compared with testing the first model with the readability index, it can be concluded that several control variables used do not significantly affect the readability of financial statements, but rather affect the length of disclosure.

\section{CONCLUSION}

The researcher found that IFRS adoption in Indonesia had a negative and significant effect on the readability of financial statement disclosures in Indonesia. In addition to seeing the effect of IFRS adoption on the readability of annual reports, the test results also found that control variables did not have a significant effect on the readability of company financial statement disclosures in Indonesia, except for volatility control variables and energy industry classifications. The researcher also conducted a robustness test using a projection length of disclosure as a measure of readability. while the test results with a long disclosure proxy indicate that there is a significant relationship between the variables of firm size, leverage, and industry classification on the readability of annual report disclosures.

The results of this study indicate that IFRS adoption can result in disclosure of reports that are increasingly difficult to read. This study has implications for users of financial statements in Indonesia. The implication of this study is that financial report readers are required to have higher competence in understanding IFRS-based financial statements. If seen from the readability value of sample companies, the level of education equivalent to undergraduate students accounting to postgraduate is needed in understanding financial statements. In addition to taking education equivalent to accounting students, financial report users can also take additional education/accounting-related training to be able to better understand financial statements. In addition, financial report users can also use external assistance in understanding financial statements after the period of IFRS adoption.

This study has several limitations. First, this study uses a readability formula, which only considers the length of the word and the length of the sentence. In addition, the readability formula also does not consider the meaning of the sentence 
from the text being measured, which can also influence the understanding of the text [16]. Therefore, further research can contribute by:

1. Using investigations based on survey or content analysis to determine changes in the level of readability, or using Cloze procedures [34].

2. Using more predictor variables, such as auditors, company age, turnover, operating sector and senior management indicators, to understand other things that affect the disclosure of annual reports.

3. Conduct separate analysis for each stage of IFRS adoption process.

\section{REFERENCES}

[1] Al-Tuwaijri, S., Christensen, T., and Hughes, K. (2004). The relations among environmental disclosure, environmental performance, and economic performance: a simultaneous equations approach. Accounting, Organizations and Society, 29(5), 447-471.

[2] Bayerlein, L. and Davidson, P. (2012). The influence of connotation on readability and obfuscation in Australian chairman addresses. Managerial Auditing Journal, 27(2), 175198.

[3] BenAmar, W., and Belgacem, I. (2018). Do socially responsible firms provide more readable disclosures in annual reports? Corporate Social Responsibility and Environmental Management, 25(5), 1009-1018.

[4] Bonsall, S. B., and Miller, B. P. (2017). The Impact of Narrative Disclosure Readability on Bond Ratings and The Cost of Debt. Review of Accounting Studies, 22(2), 608-643.

[5] Bradbury, M. (1992). Voluntary disclosure of financial segment data: New Zealand evidence. Accounting and Finance, 32(1), 15-26.

[6] Cahyonowati, N., and Ratmono, D. (2012). Adopsi IFRS dan Relevansi Nilai Informasi Akuntansi. Jurnal Akuntansi dan Keuangan, 14(2), 105-115.

[7] Courtis, J.K. (1986). An investigation into annual report readability and corporate riskreturn relationships. Accounting and Business Research, 16 (64), 285-295.

[8] Dempsey, S.J., Harrison, D.M., Luchtenberg, K.F. and Seiler, M.J. (2012). Financial opacity and firm performance: the readability of REIT annual reports. Journal of Real Estate Finance and Economics, 45(2), 450-470.

[9] Elliott, A.C., and Woodward, W.A., Statistical analysis quick reference guidebook with SPSS examples, First Edition, Sage Publications., London, 2007.
[10] Flory, S.M., Phillips, T., and Tassin, M.F. (1992). Measuring readability: a comparison of accounting textbooks. Journal of Accounting Education, 10(1), 151-161.

[11] Gelman, A., and Hill, J., Data analysis using regression and multilevel hierarchical models, Vol. 1, Cambridge University Press., New York, USA, 2007.

[12] Gujarati, D., Basic Econometrics, United States Military Academy., West Point, 2004.

[13] Hall, M. (2009). IFRS accounting changes bedevil the bottom line. National Business Review.

[14] Hasan, M. M. (2018). Readability of narrative disclosures in 10-K reports: Does managerial ability matter? European Accounting Review, $1-22$

[15] Jang, M. H., and Rho, J. H. (2016). IFRS adoption and financial statement readability: Korean evidence. Asia-Pacific Journal of Accounting \& Economics, 23(1), 22-42.

[16] Jones, M. J. (1996). Readability of annual reports: Western versus Asian evidence-a comment to contexualize. Accounting, Auditing \& Accountability Journal, 9(2), 86-91.

[17] Lehavy, R., Li, F., and Merkley, K. (2009). The effect of annual report readability on analyst following and the properties of their earnings forecasts. Working Paper, University of Michigan, $1-52$.

[18] Li, F. (2008). Annual report readability, current earnings, and earnings persistence. Journal of Accounting and Economics, 45(2/3), 221-247.

[19] Lim, E. K., Chalmers, K., and Hanlon, D. (2018). The influence of business strategy on annual report readability. Journal of Accounting and Public Policy, 37(1), 65-81.

[20] Lo, K., Ramos, F., and Rogo, R. (2017). Earnings management and annual report readability. Journal of Accounting and Economics, 63(1), 1-25.

[21] Martani, D. (2017). Perkembangan PSAK s/d 2017. https://staff.blog.ui.ac.id/martani/files/2017 /11/Perkembangan-PSAK-16112017-singkat. pptx.

[22] McGregor, W. (2012). In defense of IFRS financial statements. CPA Australia Ltd.

[23] Mogul, S.S. (2003). Harmonization of accounting standards. http://www.icai.org/resource_ file/11430p681-684.pdf.

[24] Morunga, M., and Bradbury, M. E. (2012). The Impact of IFRS on Annual Report Length. Australasian Accounting Business and Finance Journal, 5 (6), 48-62.

[25] Nachrowi, D. N., and Usman, H., Pendekatan Populer dan Praktis Ekonometrika untuk Analisis Ekonomi dan Keuangan, dilengkapi Teknik Analisis dan Pengolahan Data dengan 
SPSS dan Eviews, Penerbit Fakultas Ekonomi Universitas., Jakarta, Indonesia, 2006.

[26] Pallant J., SPSS survival manual, a step by step guide to data analysis using SPSS for windows, Third Edition, McGraw Hill., Sydney, 2007.

[27] Pashalian, S., and Crissy, W. (1950). How readable are corporate annual reports? Journal of Applied Psychology, 34(4), 244-248.

[28] Patralalita, C. W., and Juliarto, A. (2014). Dampak adopsi IFRS terhadap panjang laporan keuangan pada perusahaan yang terdaftar di BEI. Doctoral Dissertation. Fakultas Ekonomika dan Bisnis, Universitas Gadjah Mada.

[29] Petreski, M. (2006). The Impact of International Accounting Standard on Firms. http:// papers.ssrn.com/sol3/papers.cfm?abstract_id= 901301.

[30] Pricewaterhouse Coopers. (2013). IFRS and Indonesia GAAP (IFAS): Similarities and Differences. https://www.pwc.com/id/en/publications/assets/assurance/acs/ifrs-and-indonesiagaap-ifas-2016-r1.pdf.

[31] Richards, G., and Van Staden, C. (2015). The readability impact of international financial reporting standards. Pacific Accounting Review, 27(3), 282-303.

[32] Smith, M., and Taffler, R. (1992). Readability and understandability: Different measures of the textual complexity of accounting narrative. Accounting, Auditing \& Accountability Journal, 5(4).
[33] Schroeder, N., and Gibson, C. (1990). Readability of management's discussion and analysis. Accounting Horizons, 4(4), 78-87.

[34] Stevens, K.T., Stevens, K.C., and Stevens, W.P. (1992). Measuring the readability of business writing: the cloze procedure versus readability formulas. Journal of Business Communication, 29(4), 367-378.

[35] Subramanian, R., Insley, R., and Blackwell, R. (1993). Performance and readability: a comparison of annual reports of profitable and unprofitable corporations. Journal of Business Communication, 30(1), 4-61.

[36] Suprihatin, S., and Tresnaningsih, E. (2013). Dampak Konvergensi International Financial Reporting Standards Terhadap Nilai Relevan Informasi Akuntansi. Jurnal Akuntansi dan Keuangan Indonesia, 10(2), 171-183.

[37] Sydserff, R., and Weetman, P. (1999). A texture index for evaluating accounting narratives: an alternative to readability formula. Accounting, Auditing \& Accountability Journal, 12(4), 459-488.

[38] Worthington, J. (1978). Footnotes: readability or liability. The CPA Journal, 48(5), 27-32.

[39] Zamzami, F. (2011). Perkembangan Konvergensi International Financial Reporting Standards (IFRS) di Indonesia. Seminar dan Pelatihan IFRS Serta Penyusunan Kamus Akuntansi Indonesia P2EB UGM. 